\title{
SVEIKATOS PRIEŽIŪROS ORGANIZACIJŲ DARBUOTOJŲ NUSITEIKIMAS SKIEPYTIS COVID-19 VAKCINA: SISTEMINE் LITERATŪROS APŽVALGA IR METAANALIŻ்
}

\author{
Vinsas Janušonis \\ Klaipèdos universitetas, Klaipédos universitetine ligoninè
}

Raktažodžiai: sveikatos priežiūros organizacijų darbuotojai, Covid-19 vakcina, medikų nusiteikimas skiepytis.

\begin{abstract}
Santrauka
Straipsnyje apžvelgiamas sveikatos priežiūros organizacijų (SPO) darbuotojų nusiteikimas skiepytis Covid-19 vakcina pasaulyje.

Tyrimo tikslas - apžvelgti sveikatos priežiūros organizacijų darbuotojų nusiteikimo skiepytis Covid-19 vakcina apimtis, priežastis, ypatumus bei tendencijas įvairiose šalyse.

Atliekant tyrimą, analizuoti ịvairių šalių autorių moksliniai tyrimai ir publikacijos. Atskleisti nusiteikimą skiepytis skatinantys sisteminiai veiksniai ir nenoro skiepytis priežastys. Pateikti įvairių šalių duomenys dẻl nusiteikimo (ar nenusiteikimo) skiepytis Covid-19 vakcina. Nustatyta, kad sveikatos priežiūros organizacijų darbuotojų nusiteikimas skiepytis Covid-19 vakcina daugiau ar mažiau koreliuoja su tos šalies visuomenès nusiteikimu skiepytis ir yra svarbus Covid-19 pandemijos valdymo veiksnys.
\end{abstract}

\section{Ivadas}

Covid-19 (SARS-CoV-2) pandemiją PSO paskelbė 2020 $\mathrm{m}$. kovo $21 \mathrm{~d}$. Tai penkta pandemija žmonijos istorijoje [1]. $2021 \mathrm{~m}$. sausio pabaigoje Covid-19 virusu buvo infekuota daugiau kaip 100 milijonų žmonių ir užregistruota 2,25 milijono su Covid-19 virusu susijusių mirčių. Kai kurie autoriai mano, kad šie skaičiai yra 3-20 kartų mažesni, nei realūs [2]. Visi šie skaičiai priklauso nuo testavimo politikos ir metodų, diagnostikos metodologijos ir kitų priežasčių įvairiose šalyse [3].

Ši pandemija pasižymi tuo, kad Covid-19 (SARS-CoV-2) virusas labai greitai plinta, o susirgimų ir mirčiu skaičius (dalis) yra aukštesnis [4-6]. Šis mažai ištirtas virusas (SARSCoV-2) paveikè visus žmogaus gyvenimo aspektus [7,8]. Greta Covid-19 ligos plitimo bei mirčių, pandemija sukèlè didelę socialinę, medicininę, ekonominę ir psichologinę destrukciją visuomenèje, jos susipriešinimą.

Medikų užsikrettimo Covid-19 virusu ir mirties rizika nuo 1,4 iki 20 kartų didesnè, nei visos populiacijos [9-13]. 2020 m. pradžioje bendras susirgusių Covid-19 liga mirtingumas pasaulyje buvo apie 3,4 proc., mediku - apie 1,4 proc., tačiau kai kuriose šalyse sveikatos priežiūros organizacijų (SPO) darbuotojų mirtingumas buvo daug didesnis (Italijoje - 9 proc.) [14]. Europoje, ypač rytiniame Viduržemio regione, buvo daugiausia SPO darbuotojų susirgimų ir jų mirčiu [15].

Daug didesnis mirtingumas medikų, dirbančių intensyviosios terapijos ir reanimacijos skyriuose su Covid-19 sergančiais pacientais $[16,155]$.

Medikams, SPO darbuotojams, teikiantiems ar padedantiems teikti sveikatos priežiūrą Covid-19 liga sergantiems pacientams, kilo daug ir įvairių iššūkių - mirties ir ligos baimè, didžiuliai darbo krūviai, ilgas darbo laikas, darbas su asmens apsaugos priemonėmis, psichologinis distresas, stigma, pacientų, jų giminių, politikų, visuomenès informacijos priemonių spaudimas ir kt. [17,18], todèl pandemijos laikotarpiu pasitaikè ir medikų savižudybių $[14,150]$. Tiriant savižudybes išsivysčiusiose šalyse, pirmosios Covid-19 bangos metu jų skaičius nedidejjo $[19,20]$. Paskelbta mokslinių tyrimų, kuriuose nurodoma, kad medikai rečiau hospitalizuojami ir patenka ị reanimacijos skyrius, gal būt dèl to, kad jie jaunesni, sveikesni, mažiau turi kitų gretutinių ligų ir jų geresnis sveikatos priežiūros prieinamumas, nei kitos visuomenès dalies [21].

Bet kuriuo atveju medikų, dirbančių su Covid-19 sergančiais ar infekuotais pacientais, rizikos laukas yra didelis, jie turi priimti greitus sprendimus, jausdami didžiuli politikų, visuomenès, pacientų ir jų giminių spaudimą, esant labai dideliems darbo krūviams ir nenormalioms darbo sąlygoms [22-24]. Kita vertus, medikai, kaip viena didžiausios rizikos grupių, yra ne tik patys pažeidžiami, bet ir Covid-19 viruso platintojai, todèl jų nenoras, nenusiteikimas skiepytis kelia 
pavojų jiems ir visuomenei. Medikų nusiteikimas ar nenusiteikimas skiepytis Covid-19 vakcina susijęs su dar viena problema - kitomis ligomis sergančių pacientų sveikatos priežiūra, ligų prevencija, sveikatos priežiūros kokybès gerinimu pandemijos laikotarpiu [25], todèl sveikatos priežiūros organizacijų darbuotojų nusiteikimas skiepytis Covid-19 vakcina, jo priežastys ir aplinkybès yra labai aktuali tema.

Tyrimo tikslas - apžvelgti sveikatos priežiūros organizacijų darbuotojų nusiteikimo skiepytis Covid-19 vakcina apimtis, priežastis, ypatumus bei tendencijas įvairiose šalyse.

\section{Tyrimo medžiaga ir metodai}

Tyrimo objektas - sveikatos priežiūros organizacijų darbuotojų nusiteikimas skiepytis Covid-19 vakcina.

Tyrimo metodai: mokslinès literatūros ir mokslinių tyrimų analizè, grupavimas, interpretavimas bei apibendrinimas, lyginamoji ir turinio analizè.

Sisteminė literatūros apžvalga ir metaanalizè vykdyta atsižvelgiant ị mokslines rekomendacijas [26].

Literatūra (moksliniai straipsniai) rinkta naudojantis duomenų bazėmis - PubMed Medicine, EBSCO Publishing, BMJ, SpringerLink, Sage Journals Online, Cohrane Library, DOAJ, Google Scholar, Public library of science (PLOS), Medline.

\section{Tyrimo rezultatai}

Sisteminė literatūros apžvalga ir metaanalizè. Su Covid-19 pandemija susijusią gyventojų sveikatą veikia ne tik pati pandemija, bet ir jos įtaka socialiniams sveikatą lemiantiems veiksniams, tokiems kaip rasizmas, istorinè trauma, sveikatos netolygumai, socialinis ir sveikatos teisingumas, kiti. Šie veiksniai formuoja skirtingą sveikatos priežiūrą ịvairaus amžiaus, seksualinès orientacijos, lytiškumo, rasės ir kitokių išskirtinumų žmonèms [27-31,151].

Covid-19 pandemijos metu stebima, kad ligos plitimui, sunkumui ir mirtingumui nuo jos nemažą ịtaką turi etniškumas - baltieji medikai, kaip ir kita tos pačios visuomenès dalis, serga palyginti lengviau ir miršta rečiau, nei kitos etninès grupès [32-34]. Vertinant etniškumo ịtaką Covid-19 infekuotų ir sergančiu SPO darbuotojų sveikatai, būtina atsižvelgti i jų amžių, lytį, socialinius - ekonominius veiksnius ir vaidmenį, teikiant sveikatos priežiūrą Covid-19 sergantiems pacientams [35].

Plataus masto pasaulinis tyrimas parodè, kad 71,5 proc. žmonių daugiau ar mažiau nusiteikę skiepytis Covid-19 vakcina [36]. Vyrai, tarp jų ir medikai, labiau nusiteikę skiepytis Covid-19 vakcina, nei moterys - tai susiję su moteru vaidmeniu visuomeneje ir šeimoje, rūpinimusi vaikais ir kt. [37-39]. Vyrų imuninis atsakas ị skiepus yra silpnesnis, nei moterų [40].
Nagrinejjant SPO darbuotojų nusiteikimą ar nenusiteikimą skiepytis, mokslines publikacijas šia tema, svarbu suprasti, ką ši sąvoka reiškia, kokị kontingentą tiriamujų ji aprėpia.

Literatūroje sutinkame įvairių terminų, charakterizuojančių sveikatos priežiūros organizacijų personalą - gydytojai, slaugytojai, akušeriai, medikai, sveikatos priežiūros organizacijų darbuotojai, paramedikai, pagalbinis personalas ir kt. PSO sveikatos priežiūros darbuotojus apibrēžia kaip visus darbuotojus, įtrauktus ị veiklą, kurios pagrindinis tikslas stiprinti, palaikyti žmonių sveikatą [41].Toks apibrěžimas apjungia visus aukščiau ịvardintus terminus. SPO darbuotojai - tai visas SPO personalas.

Žmonių, tarp jų SPO darbuotojų, nenusiteikimas (nenoras, neapsisprendimas ar svyravimas) skiepytis yra daugelio aplinkybių, aplinkos bei individualių žmogaus charakteristikų visumos išdava. Individualiame lygmenyje nusiteikimą ar nenusiteikimą skiepytis apsprendžia: pasitikejjimas (a), pasitenkinimas (b), patogumas (c), rizikos įvertinimas (d) ir kolektyvinè atsakomybė (e) $[42,43]$. Tai bendri principai, kurių kontekste reikia vertinti šali, aplinką, tradicijas, religiją, rasę, mokslo lygị, visuomenès ir individų charakteristikas, išsilavinimo lygị, visuomenès informacijos sklaidą, prieigą prie interneto ir daugeli kitu dedamujų . Didejjant individo rizikos laipsniui susirgti Covid-19 liga, nusiteikimas skiepytis taip pat didejja [44]. Vis dèlto tikèjimas, pasitikèjimas ir atsakomybė yra pagrindiniai veiksniai, darantys ịtaką nusiteikimui skiepytis Covid-19 vakcina $[45,46,152]$.

Žmonių nenusiteikimas, nenoras vakcinuotis paplitęs visose pasaulio šalyse ir nėra išsamiai moksliškai paaiškinamas $[36,47,153]$, ypač kai tai vyksta tokiose šalyse, kaip JAV, Italija, Prancūzija, Rusija, kur buvo nenusiteikę skiepytis Covid-19 vakcina per 40 proc. gyventojų [48].

Nagrinėjant SPO darbuotojų nusiteikimą skiepytis Covid-19 vakcina, daugelyje publikacijų teigiama, kad nenorinčių skiepytis SPO darbuotojų dalis yra panaši į visų gyventojų, ar net didesnè [49-52]. Pagrindinès vengimo skiepytis Covid-19 vakcina priežastys - nepageidautinu ivvkių po skiepų baimè, abejojimas vakcinos saugumu ir efektyvumu, informacijos trūkumas apie vakciną ir kt. [44, 53-56]. Čia nemažą poveikị daro visuomenès informacijos priemonès, ypač socialiniai tinklai. Juose skleidžiama daug nepatikslintos, netikslios ar net melagingos informacijos, kurią PSO pavadino infodemija [57-59, 154].

Sveikatos priežiūros sektoriaus darbuotojai dèl Covid-19 pandemijos priskiriami kritinei infrastruktūrai. Italijoje pirmosios Covid-19 bangos metu net 10 proc. visų infekuotujų Covid-19 buvo sveikatos priežiūros sektoriaus darbuotojai [60]. Medikų sergamumas ir mirtingumas dè šios ligos didelis ir kitose šalyse [61-63,155], todèl jie turètų būti skiepijami (daugumoje šalių taip ir vyksta) pirmiausiai $[3,25,64,65]$. 
Kita vertus, medikų skiepijimasis yra tiesiogiai susietas su pacientu skiepijimusi - jeigu skiepijasi medikai, skiepijasi ir pacientai $[66,67]$. Yra stiprios sąsajos tarp medikų žinių apie vakcinas ir jų nusiteikimo skiepytis bei rekomenduoti tai daryti savo pacientams $[68,69]$.

Atskira problema - infekuotumas ar susirgimas Covid-19 po vakcinacijos (pasitaiko dažniau) ar po buvusio SPO darbuotojų infekuotumo ar ligos (pasitaiko rečiau). Pasiskiepiję Covid-19 vakcina SPO darbuotojai gali būti potencialūs viruso perdavejai, todèl jie turi pastoviai testuotis ir dèveti asmens apsaugos priemones [70-72]. Tuo labiau, kad apie trečdalis infekuotų pacientų, taip pat ir medikų, nejaučia simptomų [73]. Ir nesiskiepiję Covid-19 vakcina, ir pasiskiepiję ar persirgę Covid - 19 liga SPO darbuotojai yra potencialūs viruso platintojai tarp kolegų, pacientų ir lankytojų [55, 74]. Potencialūs Covid-19 viruso platintojai, ypač nesiskiepiję, yra kolegijų ir universitetų studentai, atliekantys praktiką, dèl didelio jų judumo bei kontaktų SPO viduje ir išoreje [70-76]. Persirgę ar galimai persirgę Covid-19 liga ir dirbantys su Covid-19 pacientais medikai labiau linkę nesiskiepyti. Mažiau linkę skiepytis slaugytojai, slaugytojų padejjèjai, kineziterapeutai $[77,78]$.

Nepaisant nuomonių įvairovès, vakcinacija yra viena svarbiausių priemonių suvaldyti Covid-19 pandemiją. Visų pirma, turima galvoje visuotinè vakcinacija, padésianti pasiekti kolektyvinį imunitetą - mažiausiai apie 67 proc. gyventojų, jeigu vakcinų efektyvumas būtų 100 proc. [54, 79, 80]. Kitų autorių duomenimis, kolektyvinis imunitetas pasiekiamas paskiepijus Covid-19 vakcina 69,6 - 90 proc. gyventojų [78, 81]. Keičiantis Covid-19 viruso padermèms, kyla tam tikrų abejonių dèl kolektyvinio imuniteto, tačiau skiepijimu Covid-19 vakcina abejoti nereikètų. Antai Izraelyje 2021 metų spalio pirmoje pusėje trečiaja, sustiprinamaja Covid-19 vakcinos doze jau buvo paskiepyta 54 proc. suaugusių gyventojų.

Sunkių ir kritinès būklès ligonių tarp nesiskiepijusių per $60 \mathrm{~m}$. gyventojų buvo 126, tarp visiškai pasiskiepijusių (be trečiosios dozès) - 21, tarp pasiskiepijusių trimis dozèmis - 2 žmonès 100 tūkstančių gyventojų. Nors šie skaičiai varijuoja laike, tačiau aiškiai parodo Covid-19 vakcinos naudą. Izra-

1 lentelè. Sveikatos priežiūros organizacijų darbuotojų nusiteikimas skiepytis Covid-19 vakcina (aukščiausi rodikliai, $\mathrm{n}=15$ ). $S P O D$ - sveikatos priežiūros organizacijų darbuotojai.

\begin{tabular}{|c|c|c|c|c|c|c|}
\hline Autoriai & Šalis & Kontingentas & $\begin{array}{l}\text { Tyrimo ap- } \\
\text { imtys } \\
\text { (tiri a m ų j uc } \\
\text { skaičius) } \\
\end{array}$ & Tyrimo data & $\begin{array}{l}\text { Nusiteikę skiepytis, } \\
\text { proc. }\end{array}$ & Pastabos \\
\hline Chew N.W., et al. [95] & Azija & SPOD & 1720 & $2020 \mathrm{~m}$. gruodis & 96 & - \\
\hline $\begin{array}{l}\text { Castaneda-Vasquez D., } \\
\text { et al.[96] }\end{array}$ & Meksika & SPOD & 43 & $\begin{array}{l}2020 \mathrm{~m} . \\
\text { spalis - lapkritis }\end{array}$ & 94 & - \\
\hline Parajuli J., et al.[92] & Nepalas & SPOD & 230 & $\begin{array}{l}2020 \mathrm{~m} . \text { balandis - } \\
\text { gegužè }\end{array}$ & 94 & - \\
\hline Hall V.J., et al. [94] & JK & SPOD & 29378 & 2020-2021 m. & 89 & \\
\hline $\begin{array}{l}\text { Schrading W.A, } \\
\text { et al.[135] }\end{array}$ & JAV & SPOD & 1542 & $2021 \mathrm{~m}$. sausis & 86 & \\
\hline Barello S., et al.[136] & Italija & $\begin{array}{l}\text { Medicinos stu- } \\
\text { dentai }\end{array}$ & 551 & $2020 \mathrm{~m}$. & 86 & $\begin{array}{l}\text { Tirti tik stu- } \\
\text { dentai }\end{array}$ \\
\hline Zigron A., et al.[137] & Izraelis & SPOD & 506 & $\begin{array}{l}2020 \mathrm{~m} . \\
\text { kovas - balandis }\end{array}$ & 85 & - \\
\hline Kaplan A.K., et al.[118] & Turkija & SPOD & 1574 & $2020 \mathrm{~m}$. gruodis & 85 & \\
\hline Grumbach K., et al.[140] & JAV & SPOD & 1803 & $2020-2021 \mathrm{~m}$. & 84 & \\
\hline Szmyd B., et al.[125] & Lenkija & SPOD & 1971 & $2020-2021 \mathrm{~m}$. & 83 & \\
\hline Gruner S., et al.[138] & Vokietija & $\begin{array}{l}\text { Sveikatos priežiū- } \\
\text { ros profesionalai ir } \\
\text { studentai }\end{array}$ & 2077 & $\begin{array}{l}2020 \text { m. gegužè-rug- } \\
\text { pjūtis }\end{array}$ & $\begin{array}{l}83 \text { sveikatos priežiū- } \\
\text { ros profesionalai } \\
79,8 \text { sveikatos prie- } \\
\text { žiūros studentai } \\
\end{array}$ & $\begin{array}{l}\text { Netirti kiti } \\
\text { SPOD }\end{array}$ \\
\hline Gonullu E., et al.[120] & Turkija & SPOD & 506 & $2020 \mathrm{~m}$. lapkritis & 83 & \\
\hline Oliver K., et al. [139] & JAV & SPOD & 1933 & $2020-2021 \mathrm{~m}$. & 81 & \\
\hline Desveaux L., et al.[100] & Kanada & SPOD & 8634 & $2021 \mathrm{~m}$. sausis & 80 & \\
\hline $\begin{array}{l}\text { Gagneux-Brunon A., } \\
\text { et al.[39] }\end{array}$ & Prancūzija & SPOD & 2047 & $\begin{array}{l}2020 \mathrm{~m} . \\
\text { kovas-liepa }\end{array}$ & 77 & \\
\hline
\end{tabular}


elyje nors viena Covid-19 vakcinos doze yra pasiskiepiję 66,7 proc. gyventoju.

Žmonių nuomonių dèl Covid-19 vakcinacijos ịvairovè, dalinis jų nepasitikejjimas vakcinomis sunkina visuotinę vakcinaciją, kuri tampa tam tikru iššūkiu $[82,83]$. Nèra aiškaus atsakymo, kiek laiko viena ar kita Covid-19 vakcina bus veiksminga, ar veiks visas Covid-19 viruso padermes, koks vakcinos apsaugos nuo Covid-19 ligos laipsnis, pačios vakcinos saugumas ir kt. [46, 84]. Abejojimas vakcinacijos nauda yra viena didžiausių pandemijų suvaldymo kliūčių $[44,85]$.

Nusiteikimas vakcinuotis - tai pasiruošimas ir noras skiepytis, vakcinos priimtinumas, patrauklumas ir pageidavimas ją gauti, vakcinos paklausa ir teigiamas požiūris ị ją [86]. Apie du trečdaliai SPO darbuotojų nusiteikę skiepytis Covid-19 vakcina [82].

Pasiruošusių (nusiteikusių) skiepytis Covid-19 vakcina SPO darbuotojų dalis svyruoja ịvairiose šalyse nuo 27,733,1 proc. [87- 89] iki $75-77,3$ procento[39, 56, 90].
Kitų autorių duomenimis, svyravimai dar didesni - nuo 23 proc. nusiteikusių skiepytis SPO darbuotojų [91] iki 89 96 procentų [92- 98]. SPO darbuotojų nusiteikimo skiepytis analizè pateikiama 1-3 lentelèse.

Vertinant JAV SPO darbuotojų nusiteikimą skiepytis Covid-19 vakcina, tik 36 proc. tvirtai nurodé, kad skiepytųsi esant galimybei [38].

Pagrindinès nenoro, nenusiteikimo skiepytis priežastys - abejonès vakcinos saugumu ir efektyvumu dèl labai greito vakcinos sukūrimo, galimų nepageidautinų įvykių po vakcinacijos, skirtingų ekspertų nuomonių, vakcinacijos proceso politizavimo, informacijos apie vakcinas nepakankamumo [38, 53, 77, 79, 99-102].

Daugiau nei trečdalis $(41,3$ proc.) tirto kontingento nurodè, kad reikètų ilgesnio laiko Covid-19 vakcinos patikimumui nustatyti, pagerinti jos komfortabilumą $(10,96$ proc.), saugumą (5,23 proc.), îvertinti patirtị (5,78 proc.), patikimesnių klinikinių tyrimų (5,78 proc.) [64].

2 lentelè. Sveiktos priežiūros organizacijų darbuotojų nusiteikimas skiepytis Covid-19 vakcina (žemiausi rodikliai, n=15). $S P O D$ - sveikatos priežiüros organizacijų darbuotojai.

\begin{tabular}{|c|c|c|c|c|c|c|}
\hline Autoriai & Šalis & $\begin{array}{l}\text { Kontin- } \\
\text { gentas }\end{array}$ & \begin{tabular}{|c|} 
Tyrimo \\
apimtys \\
(tiriamųjų \\
skaičius) \\
\end{tabular} & Tyrimo data & $\begin{array}{l}\text { Nusiteikusiųjų } \\
\text { skiepytis, proc. }\end{array}$ & Pastabos \\
\hline Temsah M., et al.[145] & Saudo Arabija & SPOD & 2007 & $2020 \mathrm{~m}$. lapkritis & $9-24$ & $\begin{array}{l}\text { Priklausomai nuo } \\
\text { vakcinos }\end{array}$ \\
\hline Kukreti S., et al [91] & Taivanas & SPOD & 500 & $\begin{array}{l}2020 \mathrm{~m} . \text { rugsèjis - } \\
\text { gruodis }\end{array}$ & 23 & - \\
\hline Nzaji M.K., et al.[87] & $\begin{array}{l}\text { Kongo Demokra- } \\
\text { tinė Respublika }\end{array}$ & SPOD & 613 & $\begin{array}{l}2020 \mathrm{~m} . \\
\text { kovas - balandis }\end{array}$ & 28 & - \\
\hline Gadoth A., et al.[89] & JAV & SPOD & 609 & \begin{tabular}{|l|}
$2020 \mathrm{~m}$. rugsejjis - \\
spalis
\end{tabular} & 32 & Netirti gydytojai \\
\hline $\begin{array}{l}\text { Agyekum M.W., } \\
\text { et al.[142] }\end{array}$ & Gana & SPOD & 234 & $\begin{array}{l}2021 \mathrm{~m} . \text { sausis- } \\
\text { vasaris }\end{array}$ & 39 & - \\
\hline Wang K., et al.[111] & Honkongas & SPOD & 806 & \begin{tabular}{|l|}
$2020 \mathrm{~m}$. vasaris - \\
kovas
\end{tabular} & 40 & Tirti tik gydytojai \\
\hline Rabi R., et al.[147] & Palestina & SPOD & 639 & $2021 \mathrm{~m}$. sausis & 40 & $\begin{array}{l}\text { Tirti tik slaugy- } \\
\text { tojai }\end{array}$ \\
\hline Papagiannis D., et al.[146] & Graikija & SPOD & 461 & $2020 \mathrm{~m}$. vasaris & 43 & - \\
\hline Patelarou E., et al.[124] & Europos šalys & SPOD & 2249 & $2020 \mathrm{~m}$. gruodis & 44 & $\begin{array}{l}\text { Tirti tik slaugos } \\
\text { studentai }\end{array}$ \\
\hline Unroe K.T., et al.[102] & JAV & SPOD & 8243 & $2020 \mathrm{~m}$. lapkritis & 45 & $\begin{array}{l}\text { Slaugos namų dar- } \\
\text { buotojai }\end{array}$ \\
\hline $\begin{array}{l}\text { Mohamed-Hussein A.A., } \\
\text { et al.[141] }\end{array}$ & Egiptas & SPOD & 496 & $2021 \mathrm{~m}$. sausis & 46 & - \\
\hline Verger P., et al.[107] & $\begin{array}{l}\text { Prancūzija, Bel- } \\
\text { gija, Kanada }\end{array}$ & SPOD & 1623 & \begin{tabular}{|l|}
2020 m. spalis-lap- \\
kritis
\end{tabular} & 46 & - \\
\hline Chawe A., et al.[144] & Zambija & SPOD & 208 & 2020 m. birželis & 47 & Tirti tik medikai \\
\hline Raftopoulos V., et al.[123] & Graikija, Kipras & SPOD & 2238 & $2020 \mathrm{~m}$. gruodis & 48 & - \\
\hline Fonogue J.Y., et al.[143] & Kamerūnas & SPOD & 464 & $2020 \mathrm{~m}$. balandis & 49 & - \\
\hline
\end{tabular}


Didelę įtaką neigiamam nusiteikimui vakcinuotis Covid-19 vakcina daro konspiracijos teorijos ir religiniai bei rasiniai motyvai [57, 103-105]. Be to, nèra įrodyta (neaišku), kad paskiepytieji negali perduoti Covid-19 viruso kitiems žmonèms [106].

Labiau nusiteikę vakcinuotis Covid-19 vakcina SPO darbuotojai vyrai, gydytojai, vyresnio amžiaus, labiau išsilavinę ir daugiau uždirbantys [89, 107-110].

Mediku, tiesiogiai dirbančių su Covid-19 infekuotais pacientais ir tiesiogiai nedirbančių su Covid-19 infekuotais pacientais nusiteikimas skiepytis, ịvairių autorių duomenimis, yra prieštaringas - vieni autoriai nurodo, kad tiesiogiai dirbantys su Covid-19 infekuotais pacientais labiau nusiteikę vakcinuotis [38,44,111], kiti - priešingai $[79,101]$.

Ligoninių, kitų SPO darbuotojai tiesiogiai susiduria su Covid-19 infekuotais ir sergančiais pacientais, todèl patys yra didelès rizikos lauke. Tai ịvertinę medikai turètų skiepytis patys ir rekomenduoti skiepytis pacientams - jų rekomendacijos daugeliu atvejų padeda pacientams apsispręsti vakcinuotis $[78,112,113]$, tačiau SPO darbuotojai, medikai, deja, linkę mažiau skiepytis ne tik Covid-19, bet ir kitomis vakcinomis $[52,69,114,115]$. Tai neigiamai veikia visuomenès nusiteikimą skiepytis [116, 117]. Kita vertus, pasiskiepiję SPO darbuotojai labiau teigiamai vertina vakciną ir rekomenduoja skiepytis kitiems [93, 114, 118].

Nusiteikimas skiepytis Covid-19 vakcina, skatinti tai daryti kitus ir nenoras, vengimas skiepytis, neigiamas pavyzdys kitiems - didžiulis kontrastas ir nepakankamai ištirtas reiškinys bei jo priežastys $[86,101,107]$.

Vakcinacijos, taip pat ir Covid-19 vakcina, privalomumas SPO darbuotojams yra labai diskutuotina tema - dalis medikų pasisako už privalomą, dalis - už savanorišką vakcinaciją $[106,119,120-122,156]$.

Bendras nusiteikimas skiepytis Covid-19 vakcina priklauso ir nuo pandemijos bei skiepijimosi proceso vadybos šalyje $[25,56]$, medicinos autoritetų, politikų vakcinacijos elgsenos [118, 123]. Nusiteikimas vakcinacijai Covid-19 vakcina priklauso ir nuo pasitikèjimo šalies vyriausybe jeigu žmonès (medikai) mažiau pasitiki vyriausybės sprendimais, jų nusiteikimas vakcinuotis yra žemesnis [124,125].

Būtina pažymèti tai, kad nusiteikimas skiepytis ir Covid-19 vakcinacija nèra identiški - nusiteikimas daro ịtaką asmens elgsenai vakcinacijos metu, bet jos nenulemia [105, $126,127]$.

Nusiteikimo skiepytis ir vakcinacijos elgsenos sąsajos priklauso nuo daugelio dedamujų konteksto: aplinkos, žinių, patirties, sąmoningumo, socializacijos laipsnio, ịvairių motyvacijos momentų, lūkesčių ir kt. [128, 129].

Vis dèlto pagrindinè medikų nenoro skiepytis Covid-19 vakcina priežastis - per mažai pateikiama (ir yra) įrodymų dèl vakcinavimo pranašumų ir su ja susijusių nepageidautinų ivvykių tikimybès, vakcinų saugumo ir efektyvumo [93, 99, 100], tačiau labiausiai akcentuojami galimi nepageidautini ivykiai po vakcinacijos Covid-19 vakcina, komplikacijos ar atokieji nepageidautini ivvykiai $[44,125,130]$.

Žemesnio išsilavinimo SPO darbuotojai labiau nusiteikę

3 lentelè. Sveikatos priežiūros organizacijų darbuotojų nenusiteikimas (nenoras, atsisakymas, vengimas) skiepytis Covid-19 vakcina (aukščiausi rodikliai, $\mathrm{n}=10$ ).

$S P O D$ - sveikatos priežiūros organizacijų darbuotojai.

\begin{tabular}{|c|c|c|c|c|c|c|}
\hline Autoriai & Šalis & $\begin{array}{l}\text { Kontin- } \\
\text { gentas }\end{array}$ & $\begin{array}{c}\text { Tyrimo } \\
\text { apimtys } \\
\text { (tiriamųjų } \\
\text { skaičius) }\end{array}$ & Tyrimo data & $\begin{array}{l}\text { Nenusiteikusių } \\
\text { skiepytis, proc. }\end{array}$ & Pastabos \\
\hline Nzaji M.K., et al.[87] & $\begin{array}{l}\text { Kongo Demokra- } \\
\text { tinè Respublika }\end{array}$ & SPOD & 613 & $2020 \mathrm{~m}$. balandis & 72 & $\begin{array}{l}\text { Tirtas atski- } \\
\text { ras regionas } \\
\end{array}$ \\
\hline Qattan A. et al.[148] & Saudo Arabija & SPOD & 673 & $2020 \mathrm{~m}$. gruodis & 49 & - \\
\hline Askarian M., et al.[149] & Iranas & SPOD & 1219 & 2020 m. rugpjūtis & 42 & - \\
\hline $\begin{array}{l}\text { Mohamed-Hussein A. A., et } \\
\text { al.[141] }\end{array}$ & Egiptas & SPOD & 496 & $2021 \mathrm{~m}$. sausis & 41 & - \\
\hline Ditekemena J.D., et al.[132] & $\begin{array}{l}\text { Kongo Demokra- } \\
\text { tinè Respublika }\end{array}$ & SPOD & 324 & $2020 \mathrm{~m}$. rugsejjis & 40 & $\begin{array}{l}\text { Tirtas atski- } \\
\text { ras regionas } \\
\end{array}$ \\
\hline Kwok K.O., et al.[78] & Honkongas & SPOD & 1205 & $2020 \mathrm{~m}$. balandis & 37 & - \\
\hline Schwarzinger M., et al.[116] & Prancūzija & SPOD & 124 & 2020 m. liepa & 32 & - \\
\hline Papagiannis D., et al.[146] & Graikija & SPOD & 461 & $2020 \mathrm{~m}$. vasaris & 31 & - \\
\hline Dror A.A., et al.[44] & Izraelis & SPOD & 549 & $2020 \mathrm{~m}$. kovas & 29 & - \\
\hline Verger P., et al.[107] & $\begin{array}{l}\text { Prancūzija, Bel- } \\
\text { gija, Kanada }\end{array}$ & SPOD & 2678 & $\begin{array}{l}2020 \text { m. spalis-lap- } \\
\text { kritis }\end{array}$ & 28 & - \\
\hline
\end{tabular}


nesiskiepyti Covid-19 vakcina - jie mažiau skaito ir domisi moksline informacija, jų pagrindinis informacijos šaltinis socialiniai tinklai, jie labiau tiki mitais, konspiracijos, sąmokslo, rasistinemis teorijomis ir kt. [131-134].

Nusiteikimo nesiskiepyti Covid-19 vakcina priežastys - tiek visų gyventojų, tiek SPO darbuotojų yra panašios.

Kaip jau minèta, per mažai yra ịrodymų dèl vakcinavimo pranašumų Covid-19 vakcina, vakcinų saugumo ir efektyvumo, su ja susijusių nepageidautinų ivvykių tikimybès, galimų atokių neigiamų pasekmių ir kt. Kitaip sakant, didelė nežinomybe tiek Covid-19 infekcijos, tiek ir vakcinacijos nuo jos.

Nepakankamas visuomenės, kartu ir medikų nusiteikimas skiepytis Covid-19 vakcina yra didelè medicininè, socialinè ir politine problema. Vis dèlto artimiausioje ateityje tikimasi sugrižżi į netolimą praeiti - ikipandeminị gyvenimą. Tam padètų ir maksimali vakcinacija, įskaitant SPO darbuotojus.

\section{Išvados}

1. SPO darbuotojų nusiteikimas skiepytis Covid-19 vakcina yra svarbus veiksnys, suvaldant Covid-19 pandemiją bei skatinant visuomenę skiepytis ir igyti masinị (kolektyvinị) imunitetą.

2. SPO darbuotojų nusiteikimas ar nenusiteikimas skiepytis Covid-19 vakcina priklauso nuo daugelio veiksnių - šalies kultūrinio, socialinio bei politinio konteksto, ekonominio išsivystymo, rasės, religijos, asmeninių charakteristikų ir kt.

3. SPO darbuotojų, kaip visuomenès dalies, nusiteikimas skiepytis Covid-19 vakcina daugiau ar mažiau koreliuoja su visos šalies gyventojų nusiteikimu skiepytis.

\section{Literatūra}

1. Lin YC, Kuo RL, Shih SR. Covid-19: the first documented coronavirus pandemic in history. Biomedical Journal 2020; 43:328-333.

https://doi.org/10.1016/j.bj.2020.04.007

2. Wu SL, Mertens AN, Crider YS, et al. Substantial underestimation of SARS-CoV-2 infection in the United States. Nature Communications 2020; 11:4507-4514. https://doi.org/10.1038/s41467-020-18272-4

3. Chou R, Dana T, Buckley D, et al. Epidemiology and risk factors for coronavirus infection in health care workers. Annals of Internal Medicine 2020; 173:120-136. https://doi.org/10.7326/M20-1632

4. Petersen E, Koopmans M, Go U, et al. Comparing SARS-CoV-2 with SARS-CoV and influenza pandemics. Lancet of Infections Diseases 2020; 20:e238-e244. https://doi.org/10.1016/S1473-3099(20)30484-9

5. Piroth L, Cottenet J, Mariet AS, et al. Comparison of the characteristics morbidity and mortality of Covid-19 and Seasonal influenza: a nationwide, population -based retrospective cohort study. Lancet Respiratory Medicine 2020.

https://doi.org/10.1016/S2213-2600(20)30527-0

6. Fauci AS, Lane HC, Redfield RR. Covid-19 - Navigating and uncharted. New England Journal of Medicine 2020. https://doi.org/10.1056/NEJMe2002387

7. Nicola M, Zaid A, Sohrabi C, et al. The socio-economic implications of the coronavirus pandemic (Covid-19): a review. International Journal of Surgery 2020;78:185-193.

https://doi.org/10.1016/j.ijsu.2020.04.018

8. Tsamakis K, Rizos E, Manolis AJ, et al. Covid-19 pandemic and its impact on mental health of healthcare professionals. Experimental and Therapeutic Medicine 2020; 19:3451-3453. https://doi.org/10.3892/etm.2020.8646

9. Misra -Hebert AD, Jehi L, Ji X, et al. Impact of the Covid-19 pandemic on healthcare workers risk of infections and outcomes in a large, integrated health system. Journal of General Internal Medicine 2020 .

https://doi.org/10.21203/rs.3.rs-61235/v1

10. Wei JT, Liu ZD, Fan ZW, et al. Epidemiology of and risk factors for Covid-19 infection among health care workers: a multi-center comparative study. International Journal of Environmental Research and Public Health 2020; 17:7149-7160. https://doi.org/10.3390/ijerph17197149

11. Zheng L, Wang X, Zhou C, et al. Analysis of the infection status of healthcare workers in Wuhan during the Covid-19 outbreak: a cross-sectional study Clinical Infections Diseases 2020; 72: 2109-2113. https://doi.org/10.1093/cid/ciaa588

12. Khalil A, Hill R, Ladhani S, et al. Covid-19 screening of healthcare workers in a London maternity hospital. Lancet Infections Diseases 2020.

https://doi.org/10.1016/S1473-3099(20)30403-5

13. Barrett ES, Horton DB, Roy J, et al. Prevalence of SARS-CoV-2 infection in previously undiagnosed health care workers at the on set of the U.S. Covid-19 epidemic. MedRxiv 2020. https://doi.org/10.1101/2020.04.20.20072470

14. Lakhani A, Sharma E, Kaplla S, Gupta S. Coronavirus (Covid-19) and its impact on health care workers Macleods 2020; 68:16-22.

15. Bandyopadhyay S, Baticulon RE, Kadhum M, et al. Infection and mortality of healthcare workers worldwide from Covid-19: a systematic review. BMJ Global Health 2020.

16. Cook T, Kursumovic E, Lennane S. Exclusive: deaths of NHS staff from Covid-19 analysed. Health Service Journal 2020.

https://www.hsj.co.uk

17. Salazar de Pablo V, Vaquerizo-Serrano J, Catalan A, et al. Impact of coronavirus syndromes on physical and mental health of health care workers: systematic review and meta-analysis. Journal of Affective Disorders 2020; 275:48-57. https://doi.org/10.1016/j.jad.2020.06.022 
18. Shaukat N, Ali DM, Razzak J. Physical and mental health impact of Covid-19 on healthcare workers: a scoping review. International Journal of Emergency medicine 2020; 13:40-49. https://doi.org/10.1186/s12245-020-00299-5

19. John A, Pirkis J, Gunnell D, et al. Trends in suicide during the Covid-19 pandemic. BMJ 2020. https://doi.org/10.1136/bmj.m4352

20. Appleby L, Richards N, Ibrahim S, et al. Suicide in England in the Covid-19 pandemic: early observational data from real time surveillance. The Lancet Regional Health Europe 2021. https://doi.org/10.2139/ssrn.3781695

21. Shah AAV, Wood R, Gribben C, et al. Risk of hospital admission with coronavirus disease 2019 in healthcare workers and their households: nation-wide linkage cohort study. BMJ 2020; 371:m3582.

https://doi.org/10.1136/bmj.m3582

22. Greenberg N, Docherty M, Granapragasam S, et al. Managing mental health challenger faced by healthcare workers during Covid-19 pandemic. BMJ 2020;368:m1211-m1212. https://doi.org/10.1136/bmj.m1211

23. Chen Q, Liang M, Li Y, et al. Mental health care for medical staff in China during the Covid-19 outbreak. Lancet Psychiatry 2020; 7:e15-e16. https://doi.org/10.1016/S2215-0366(20)30078-X

24. Lai J, Ma S, Wang Y, et al. Factors associated with mental health outcomes among healthcare workers exposed to coronavirus disease 2019. JAMA Network Open 2020; 3: e203976. https://doi.org/10.1001/jamanetworkopen.2020.3976

25. Janušonis V., Makarenko B., Janušonytė H. Covid-19 vakcinacijos proceso valdymo ypatumai: sisteminè literatūros apžvalga ir padèties šalyje įvertinimas. Tiltai, 2021; 1:77-100. https://doi.org/10.15181/tbb.v86i1.2261

26. Moher D, Liberati A, Tetziaff J, et al. Preferred reporting items for systematic review and meta-analyses: the PRISMA statement. PLOS Med 2009; 6: e1000097. https://doi.org/10.1371/journal.pmed.1000097

27. Owen W, Carmona R, Pomeroy C. Failing another national stress test on health disparities. JAMA 2020; 323: 1905-1906. https://doi.org/10.1001/jama.2020.6547

28. Berwick D. The moral determinants of health. JAMA 2020; 324: 225-226.

https://doi.org/10.1001/jama.2020.11129

29. Bambra C, Riordan R, Ford J, Matthews F. The Covid-19 pandemic and health inequalities. Journal of Epidemiology and Community Health 2020; 74:1-5. https://doi.org/10.1136/jech-2020-214401

30. Laster-Pirtle WN. Racial capitalism: A fundamental cause of novel coronavirus (Covid-19) pandemic inequities in the United States. Health Education and Behavior 2020:47:1-5. https://doi.org/10.1177/1090198120922942

31. Dorn A, Cooney RE, Sabin ML. Covid-19 exacerbating inequ- alities in the U.S. Lancet 2020; 395: 1243-1244.

https://doi.org/10.1016/S0140-6736(20)30893-X

32. Harrison EM, Docherty AB, Barr B, et al. Ethnicity and outcomes from Covid-19: the ISARIC CCP-UK Prospective Observational Cohort Study of hospitalized patients. Online 2020.

33. Rimmer A. Covid-19: disproportionate impact on ethnic minority healthcare workers will be explored by government. BMJ 2020; 369: m1562-m1562.

https://doi.org/10.1136/bmj.m1562

34. Mathur R, Rentsch CT, Morton C, et al. Ethnic differences in Covid-19 infection, hospitalization, and mortality: an Open SAFELY analysis of 17 million adults in England. MedRxiv 2020.

35. Valdes AM, Moon JC, Vijay A, et al. Longitudinal assessment of symptoms and risk of SARS-CoV-2 infection in healthcare workers across 5 hospitals to understand ethnic differences in infection risk. EClinical Medicine 2021. https://doi.org/10.1016/j.eclinm.2021.100835

36. Lazarus JV, Ratzan SC, Palayew A, et al. A global survey of potential acceptance of a Covid-19 vaccine. Nature Medicine $2021 ; 27: 225-228$.

https://doi.org/10.1038/s41591-020-1124-9

37. Kahn C, Beasley D. More women than men in U.S. nervous about fast rollout of Covid-19 vaccine and that's a problem. Reuters 2020.

https://www.reuters.com/article/health-coronavirus-vaccine-poll/.

38. Shekhar R, Sheikh AB, Upadhyay S, et al. Covid-19 vaccine acceptance among health care workers in the Unites States. Vaccines 2021; 9:119-123. https://doi.org/10.3390/vaccines9020119

39. Gagneux-Brunon A, Detoc M, Bruel S, et al. Intention to get vaccinations against Covid-19 in French health care workers during the first pandemic wave: A cross sectional survey. Journal of Hospital Infection 2020. https://doi.org/10.1016/j.jhin.2020.11.020

40. Biswas R. Are men more vulnerable to Covid-19 as compared to women? Biomedical Journal of Scientific and Technical Research 2020. https://doi.org/10.26717/BJSTR.2020.27.004481

41. World Health Organization. Health workers: a global profile. WHO 2020. https:/www.who.int/whr/2006/06-chap1-en.pdf

42. Betsch C, Schmid P, Heinemeier D, et al. Beyond confidence: development of a measure assessing the $5 \mathrm{C}$ psychological antecedents of vaccination. PLOS One 2018. https://doi.org/10.31234/osf.io/ytb7w

43. Brewer NT, Chapman GB, Rothman AJ, et al. Increasing vaccination: putting psychological science in to action. Psychological Science in the Public Interest 2017; 18:149-207. https://doi.org/10.1177/1529100618760521

44. Dror AA, Eisenbach N, Taiber S, et al. Vaccine hesitancy: the next challenge in the fight against COVID-19. European Journal of Epidemiology 2020, 35:775-779. 
https://doi.org/10.1007/s10654-020-00671-y

45. Rozek LS, Jones P, Menon A, et al. Understanding vaccine hesitancy in the context of Covid-19: the role of trust and confidence in a seventeen-country survey. International Journal in Public Health 2021.

https://doi.org/10.3389/ijph.2021.636255

46. Figueiredo A, Simas A, Karafilakis C, et al. Maping global trends in vaccine confidence and investigating barriers to vaccine uptake: a large-scale retrospective temporal modelling study. The Lancet 2020; 396:898-908. https://doi.org/10.1016/S0140-6736(20)31558-0

47. Khubchandani J, Sharma S, Price JH, et al. Covid-19 vaccination hesitancy in the United States: A rapid national assessment. Journal of Community Health 2021; 46:270-277. https://doi.org/10.1007/s10900-020-00958-x

48. Sallam M. Covid-19 vaccine hesitancy worldwide: A Concise systematic review of vaccine acceptance rates. Vaccines 2021; 9:160-167.

https://doi.org/10.3390/vaccines9020160

49. Dzieciolowska S, Hamel D, Gadio S, et. al. Covid-19 vaccine acceptance, hesitancy, and refusal among Canadian healthcare workers: A multicenter survey. American Journal of Infection Control 2021; 49:1152.1157.

50. Hamel L, Kirzinger A, Munana C, Brodie M. KFF Covid-19 vaccine monitor: December 2020. https://www.kff.org/coronavirus-covid-19.

51. Nguyen KH, Srivastov A, Razzaghi H, et al. Covid-19 vaccination intent, perceptions, and reasons for not vaccinating among groups prioritized for early vaccination - United States September and December 2020. Morbidity and Mortality Weekly Report 2021; 70:217-223.

https://doi.org/10.15585/mmwr.mm7006e3

52. Wilson R, Zaytseva A, Bocquier A, et al. Vaccine hesitancy and self-vaccination behaviors among nurses in Southeastern France. Vaccine 2020; 38:1144-1151. https://doi.org/10.1016/j.vaccine.2019.11.018

53. Lucia VC, Kelekar A, Afonso NM. Covid-19 vaccine hesitancy among medical students. Journal of Public Health 2020. https://doi.org/10.1093/pubmed/fdaa230

54. Fontanet A, Cauchemez S. Covid-19 herd immunity: where are we? Nature Reviews Immunology 2020; 20:583-584. https://doi.org/10.1038/s41577-020-00451-5

55. Belingheri M, Paladino ME, Riva MA. Beyond the assistance: additional exposure situations to Covid-19 for healthcare workers. The Journal of Hospital Infection 2020. https://doi.org/10.1016/j.jhin.2020.03.033

56. Raftopoulos V, Iordanou S, Katsapi A, et al. A comparative online survey on the intention to pet Covid-19 vaccine between Greek and Cypriot healthcare personnel: is the country a predictor? Human Vaccines Immunotherapy 2021. https://doi.org/10.1080/21645515.2021.1896907

57. Garret L. Covid-19: the medicine is the message. The Lancet
2020; 395: 942-943.

https://doi.org/10.1016/S0140-6736(20)30600-0

58. Burki T. The online anti-vaccine movement in the age of Covid-19. Lancet Digital Health 2020. https://doi.org/10.1016/S2589-7500(20)30227-2

59. Puri N, Coomes EA, Haghbayan H, Gunaratne K. Social media and vaccine hesitancy: new updates for the era of Covid-19 and globalized infections diseases. Human Vaccines and Immunotherapeutics 2020; 16:2586-2593.

https://doi.org/10.1080/21645515.2020.1780846

60. Felice C, Luca G, Tanna D, et al. Impact of Covid-19 outbreak on healthcare workers in Italy: results from a national E-survey. Journal of Community Health 2020; 45:675-683. https://doi.org/10.1007/s10900-020-00845-5

61. Wang D, Hu B, Hu C, et al. Clinical characteristics of 138 hospitalized patients with 2019 novel coronavirus-infected pneumonia in Wuhan. JAMA 2020; 323:1061-1069.

https://doi.org/10.1001/jama.2020.1585

62. Erdem H, Lucey DR. Healthcare worker infections and deaths due to Covid-19: a survey from 37 nations and a call for WHO to post national data on their website. International Journal of Infections Diseases 2021; 102:239-241. https://doi.org/10.1016/j.ijid.2020.10.064

63. Buerhaus P, Auerbach D, Staiger D. Older Clinician and the surge in novel Coronavirus diseases 2019/(Covid-19) JAMA 2020. https://doi.org/10.1001/jama.2020.4978

64. Roy B, Kumar V, Venkatesh A. Health care workers' reluctance to take the Covid-19 vaccine: a consumer marketing approach to identifying and overcoming hesitancy. NEJM Catalyst Innovations in Care Delivery 2020; 10.1056/CAT.20.0676.

65. Kaur SP, Gupta V. Covid-19 vaccine: a comprehensive status report. Virus Research 2020; 288: AID 198114. https://doi.org/10.1016/j.virusres.2020.198114

66. Karafillakis E, Dinca I, Apfel F, et al. Vaccine hesitancy among healthcare workers in Europe: A qualitative study. Vaccine 2016; 34:5013-5020. https://doi.org/10.1016/j.vaccine.2016.08.029

67. Bokemper SE, Huber GA, Gerber AS, et al. Timing of Covid-19 vaccine approval and endorsement by public figures. Vaccine 2021; 39:825-829.

https://doi.org/10.1016/j.vaccine.2020.12.048

68. Kose S, Mandiracioglu A, Sahin S, et al. Vaccine hesitancy of the Covid-19 by health care personnel. International Journal of Clinical Practice 2020.

https://doi.org/10.1111/ijcp.13917

69. McDonald NE, Dube E. Unpacking vaccine hesitancy among healthcare providers. EBioMedicine 2015; 2:792-793 https://doi.org/10.1016/j.ebiom.2015.06.028

70. Miller DG, Pierson L, Doernberg S. The role of medical students during the Covid-19 pandemic. Annals of Internal Medicine 2020; 173:145-146. 
https://doi.org/10.7326/M20-1281

71. Leeds C. Covid-19: health care workers, risk protection and transmission. The Lancet Regional Health-Europe 2020.

https://doi.org/10.1016/j.lanepe.2020.100022

72. Cucunawangsih C, Wijaya RS, Lugito MP, Suriapranata J. Post-vaccination cases of Covid-19 among healthcare workers at Siloam teaching hospital, Indonesia. International Journal of Infections Diseases 2021.

https://doi.org/10.1016/j.ijid.2021.05.020

73. Ward H, Atchison CJ, Whitaker M, et al. Antibody prevalence for SARS-CoV-2 in England following first peak of pandemic: REACT2 study in 100.000 adults. Infectious Diseases (except HIV/AIDS) 2020. https://doi.org/10.1101/2020.08.12.20173690

74. Nguyen L, Drew DA, Joshi A, et al. Risk of Covid-19 among frontline healthcare workers and the general community: a prospective cohort study. MedRxiv 2020.

https://doi.org/10.1101/2020.04.29.20084111

75. Riva MA, Paladino ME, Belingheri M. The role of medical students during the Covid-19 pandemic. Annals of Internal Medicine 2020; 173:858-859.

https://doi.org/10.7326/L20-1194

76. Carolan C, Davies CL, Crookes P, et al. Covid-19: disruptive impacts and transformative opportunities in undergraduate nurse education. Nurse Education in Practice 2020.

https://doi.org/10.1016/j.nepr.2020.102807

77. Kociolek LK, Elhadary J, Jhaveri R. Coronavirus disease 2019 vaccine hesitancy among children's hospital staff: a singlecenter survey. Infection Control and Hospital Epidemiology 2021; Epub ahead of print: 2021.

https://doi.org/10.1017/ice.2021.58

78. Kwok KO, Li KK, Wei WJ, et al. Influenza vaccine uptake Covid-19 vaccination intention and vaccine hesitancy among nurses. International Journal of Nursing Studies 2021; 114:103854. https://doi.org/10.1016/j.ijnurstu.2020.103854

79. Manning ML, Gerolamo AM, Marino MA, et al. Covid-19 vaccination readiness among nurse faculty and student nurses. Nursing Outlook 2021.

https://doi.org/10.1016/j.outlook.2021.01.019

80. Randolph HE, Barreiro LB. Herd immunity: understanding Covid-19. Immunity 2020; 52:737-741.

https://doi.org/10.1016/j.immuni.2020.04.012

81. Fine P, Eames K, Heymann DL. "Herd immunity": a rough guide. Clinical Infections Diseases 2021; 52:911-916.

https://doi.org/10.1093/cid/cir007

82. Fisher KA, Bloomstone SJ, Walder J, et al. Attitudes toward a potential SARS-CoV-2 vaccine. Annals of Internal Medicine 2020; 173:964-973.

https://doi.org/10.7326/M20-3569

83. Malik AA, McFadden SM, Elharake J, et al. Determinant of Covid-19 vaccine acceptance in the US. EClinicalMedicine
2020; 26:100495.

https://doi.org/10.1016/j.eclinm.2020.100495

84. Altmann DM, Douek DC, Boyton RJ. What policy markers need to know about Covid-19 protective immunity. The Lancet 2020; 395:1527-1529.

https://doi.org/10.1016/S0140-6736(20)30985-5

85. World Health Organization. Ten threats to global health in 2019.

https://www.who.int/news-room/spotlight/ten-threats-to-globalhealth-in-2019.

86. Gates A, Gates M, Rahman S, et al. A systemic review of factors that influence the acceptabillity of vaccines among Canadians. Vaccine 2021; 39:222-236. https://doi.org/10.1016/j.vaccine.2020.10.038

87. Nzaji MK, Ngombe LK, Mwamba GN, et al. Acceptability of vaccination against Covid-19 among health care workers in the Democratic Republic of the Congo. Pragmatic and Observational Research 2020; 11:103-109.

https://doi.org/10.2147/POR.S271096

88. Sim MR. The Covid-19 pandemic: major risk to healthcare and other workers on the front line. Open E-medicine 2020. https://doi.org/10.1136/oemed-2020-106567

89. Gadoth A, Halbrook M, Martin-Blais R, et al. Assessment of Covid-19 vaccine acceptance among healthcare workers in Los Angeles. MedRxiv 2020.

https://doi.org/10.1101/2020.11.18.20234468

90. Sun Y, Chen X, Cao M, et al. Will healthcare workers accept a Covid-19 vaccine when it becomes available? A Cross-sectional study in China. Frontiers in Public Health 2021.

https://doi.org/10.3389/fpubh.2021.664905

91. Kukreti S, Lu M-Y, Lin YM, et al. Willigness of Taiwan's healthcare workers and outpatients to vaccinate against Covid-19 during a period without community outbreaks vaccines 2021 . https://doi.org/10.3390/vaccines9030246

92. Parajuli J, Mishra P, Sharma S, et al. Knowledge and attitude about Covid-19 among healthcare workers working in seti provincial Hospital. Concern 2020, 3:5-5.

https://doi.org/10.33314/jnhrc.v18i3.2816

93. Fu C, Wei Z, Tei S, et al. Acceptance and preference for Covid-19 vaccination in health-care workers (HCWS). MedRxiv.

94. Hall VJ, Foulkes S, Sali A, et al. Covid-19 vaccine coverage in health-care workers in England and effectiveness of BNT162b2mRNA vaccine against infection (SIREN): a prospective, multicentre, cohort study. The Lancet 2021; 397:1725-1735. https://doi.org/10.1016/S0140-6736(21)00790-X

95. Chew NWS, Cheong C, Kong G, et al. An Asia-Pacific study on healthcare workers perceptions of and willingness to receive, the Covid-19 vaccination. International Journal of Infectious Diseases 2021; 106:52-60.

https://doi.org/10.1016/j.ijid.2021.03.069

96. Castaneda-Vasquez DE, Ruiz-Padilla JP, Botello-Hernandez E. Vaccine hesitancy against SARS-CoV-2 in health personnel of 
Northeastern Mexica and its determinants. Journal Occupational Environmental Medicine 2021.

https://doi.org/10.1097/JOM.0000000000002205

97. Amin DP, Palter JS. Covid-19 vaccination hesitancy among healthcare personnel in the emergency department deserves continued attention. American Journal of Emergency Medicine 2021 .

https://doi.org/10.1016/j.ajem.2021.01.089

98. Di Gennaro F, Murri R, Segala FV, et al. Attitudes towards AntiSARS-CoV2 vaccination among health care workers: results from a national survey in Italy. Viruses 2021; 13:371-378. https://doi.org/10.3390/v13030371

99. Verger P, Dube E. Restoring confidence in vaccines in the Covid-19 era. Expert Review of Vaccines 2020; 19:991-983. https://doi.org/10.1080/14760584.2020.1825945

100. Desveaux L, Savage R-D, Tadrous M, et al. Beliefs associated with intentions of non-physician healthcare workers to receive the Covid-19 vaccine in Ontario. Canada 2021. https://doi.org/10.1101/2021.02.19.21251936

101. Shaw J, Stewart T, Anderson KB. Assessment of U.S. health care personnel (HCP) attitudes towards Covid-19 vaccination in a large university health care system. Clinical Infectious Diseases 2021.

https://doi.org/10.1093/cid/ciab054

102. Unroe KT, Evans R, Weaver L, et al. Willigness of long-term care staff to receive a Covid-19 vaccine: a single state survey. Journal American Geriatrics Society 2021; 69:593-599.

https://doi.org/10.1111/jgs.17022

103. Gostin LO, Salmon DA, Larson HJ. Mandating Covid-19 vaccines. JAMA 2021.https://som.yak.edu/event/. https://doi.org/10.1001/jama.2020.26553

104. Thomas B, Flood CM. Eliminating religions and philosophical exemptions: the next step in Ontario's Campaign against vaccine hesitancy. Health Policy 2020; 16:14-20.

https://doi.org/10.12927/hcpol.2020.26357

105. Mandavilli A. Here's why vaccinated people still need to wear a mask. The New York Times 2020.

www.nytimes.com/2020/12/08.

106. Kreps S, Prasad S, Brownstein JS, et al. Factors associated with U.S. adults' likelihood of accepting Covid-19 vaccination. JAMA Network Open 2020; 3:e2025594.

https://doi.org/10.1001/jamanetworkopen.2020.25594

107. Ruiz JB, Bell RA. Predictors of intention to vaccinate against covid-19: results of a nationwide survey. Vaccine 2021; 9:1080-1086.

https://doi.org/10.1016/j.vaccine.2021.01.010

108. Verger P, Scronias D, Dauby N, et al. Attitudes of health care workers towards Covid-19 vaccination: a survey in France and French-speaking parts of Belgium and Canada, 2020. Euro Surveillance 2021 .

https://doi.org/10.2807/1560-7917.ES.2021.26.3.2002047
109. Neumann-Bohme S, Varghese NE, Sabat J, et al. Once we have it, will we use it? A European Survey on willingness to be vaccinated against Covid-19. European Journal of Health Economics 2020; 21:977-982.

https://doi.org/10.1007/s10198-020-01208-6

110. Baumgaertner R, Ridenhour BJ, Justwan F, et al. Risk of disease and willigness to vaccinate in the United States: a population based survey. Plos Med 2020;17: e1003354.

https://doi.org/10.1371/journal.pmed.1003354

111. Detoc M, Bruel S, Frappe P, et al. Intention to participate in a Covid-19 vaccine clinical trial ant to get vaccinated against COVID-19 in France during the pandemic. Vaccine 2020; 38:7002-7006.

https://doi.org/10.1016/j.vaccine.2020.09.041

112. Wang K, Wong ELY, Ho KF, et al. Intention of nurses to accept coronavirus diseases 2019 vaccination and change of intention to accept seasonal influenza vaccination during the coronavirus disease 2019 pandemic: A cross-sectional survey. Vaccine 2020; 38:7049-7056.

https://doi.org/10.1016/j.vaccine.2020.09.021

113. Wang J, Jing R, Lai X. Acceptance of Covid-19 vaccination during the Covid-19 pandemic in China. Vaccines 2020; 8:482-487.

https://doi.org/10.3390/vaccines8030482

114. Deem MJ. Nurses' voices matter in decisions about dismissing vaccine-refusing families. American Journal of Nursing 2018; 118:11-16. https://doi.org/10.1097/01.NAJ.0000544142.09253.e0

115. Peterson P, Meurice F, Stanberry LR, et al. Vaccine hesitancy and healthcare providers. Vaccine 2016; 34:6700-3706. https://doi.org/10.1016/j.vaccine.2016.10.042

116. Lan LHW, Lee SS, Wong NS. The Continuum of influenza vaccine hesitancy among nursing professionals in Hong Kong. Vaccine 2020; 38:6785-6793

https://doi.org/10.1016/j.vaccine.2020.08.038

117. Schwarzinger M, Watson V, Arwidson P, et al. Covid-19 vaccine hesitancy in a representative working-age population in France: A survey experiment based on vaccine characteristics. Lancet Public Health 2021. https://doi.org/10.1016/S2468-2667(21)00012-8

118. Verger P, Fressard L, Collange F, et al. Vaccine hesitancy among general practitioners and its determinants during controversies: a national cross - sectional survey in France. E Biomedicine 2015; 2:891-897.

https://doi.org/10.1016/j.ebiom.2015.06.018

119. Kaplan AK, Sahin MK, Parildar H, et al. The willingness to accept the Covid-19 vaccine and affecting factors among healthcare professionals: A cross-sectional study in Turkey. International Journal of Clinic Practice 2021. https://doi.org/10.1111/ijcp.14226

120. Gur-Arie R, Jamrozik E, Kingori P. No jab, no job? Ethical issues in mandatory Covid-19 vaccination of healthcare per- 
sonnel. BMJ Global Health 2021; 6:e004877.

https://doi.org/10.1136/bmjgh-2020-004877

121. Gonullu E, Soysal A, Atici S, et al. Pediatricians' Covid-19 experiences and views on the willingness to receive Covid-19 vaccines: a cross-section survey in Turkey. Human Vaccines and Immunotherapeutics 2021. https://doi.org/10.1080/21645515.2021.1896319

122. Maltezou HC, Theodoridou K, Ledda C, et al. Vaccination of healthcare workers: is mandatory vaccination needed? Expert Review of Vaccines 2019;18:5-13. https://doi.org/10.1080/14760584.2019.1552141

123. Black CL, Yue X, Ball SW, et al. Influenza vaccination coverage among health care personnel-United States, 2016-17 influenza season. MMWR Morbidity and Mortality Weekly Report 2017;66:1009-1015. https://doi.org/10.15585/mmwr.mm6638a1

124. Romer D, Jamieson KH. Conspiracy theories as barriers to controlling the spread of Covid-19 in the U.S. Social Science and Medicine 2020.

https://doi.org/10.1016/j.socscimed.2020.113356

125. Patelarou E, Galanis P, Mechili EA, et al. Factors influencing nursing students' intention to accept Covid-219 vaccination - a pooled analysis of seven countries. MedRxiv 2021.

https://doi.org/10.1101/2021.01.22.21250321

126. Szmyd B, Karuga FF, Bartoszek A, et al. Attitude and behaviours towards SARS-CoV-2 vaccination among healthcare workers: A cross sectional study from Poland. Vaccines 2021. https://doi.org/10.3390/vaccines 9030218

127. Garza KB. How do we close the intention-behaviour gap? Journal of American Pharmacy Association 2018; 58:240-241. https://doi.org/10.1016/j.japh.2018.04.008

128. Poque K, Jensen JL, Stancil CK, et al. Influences on attitudes regarding potential Covid-19 vaccination in the United States. Vaccines 2020; 8:582-583.

https://doi.org/10.3390/vaccines8040582

129. Atkins L, Francis J, Islam R, et al. A quide to using the theoretical Domains Framework of behaviour change to investigate implementation problems. Implementation Science 2017. https://doi.org/10.1186/s13012-017-0605-9

130. Presseau J, McCleary N, Lorencatto F, et al. Action, actor, context, target, time (AACTT): a framework for specifying behaviour. Implementation Science 2019.

https://doi.org/10.1186/s13012-019-0951-x

131. Grech V, Ganci C, Agius S. Vaccine hesitancy among Moltese family physicians and their trainees vis-a-vis influenza and novel Covid-19 vaccinations. Early Human Development 2020. https://doi.org/10.1016/j.earlhumdev.2020.105259

132. Bunch L. A tale of two crises: addressing Covid-19 vaccine hesitancy as promoting racial justice. HEC Forum 2021;33:1-12. https://doi.org/10.1007/s10730-021-09440-0

133. Ditekemena JD, Nkamba DM, Mavoko AM, et al. Covid-19 vaccine acceptance in the Democratic Republic of Congo: A cross-sectional survey. Vaccines 2021; 9:153-157.

https://doi.org/10.3390/vaccines9020153

134. Gharpure R, Guo A, Bishnoi CK, et al. Early Covid-19 firstdose vaccination coverage among residents and staff members of skilled nursing facilities participating in the pharmacy partnership for long-term care program - United States December 2020 - January 2021. Morbidity and Mortality Weekly Report 2021;70:178-188.

https://doi.org/10.15585/mmwr.mm7005e2

135. Courage KH. It's essential to understand why some health care workers are putting off vaccination.

https://www.vox.com/22214210/covid-vaccine-health-care-workers-safety-fears.

136. Schrading WA, Trent SA, Paxton JH, et al. Vaccination rates and acceptance of SARS-CoV-2 vaccination among U.S. emergency department health care personnel. Academic Emergency Medicine 2021; 28:455-458.

https://doi.org/10.1111/acem.14236

137. Barello S, Nania T, Dellafiore F, et al. Vaccine hesitancy among university in Italy during the Covid-19 pandemic. European Journal of Epidemiology 2020; 35:781-783. https://doi.org/10.1007/s10654-020-00670-Z

138. Zigron A, Dror AA, Morozov NG, et al. Covid-19 vaccine acceptance among dental professionals based on employment status during the pandemic. Frontier Medicine 2021.

https://doi.org/10.3389/fmed.2021.618403

139. Gruner S, Kruger F. The intention to be vaccinated against Covid-19: stated preferences before vaccines were available. Applied Economics Letters 2020. https://doi.org/10.31235/osf.io/wh268

140. Oliver K, Raut A, Pierre S, et al. Factors associated with Covid-19 vaccine receipt of two integrated healthcare systems in New York City: A cross sectional study of healthcare workers. MedRxiv 2021.

https://doi.org/10.1101/2021.03.24.21253489

141. Grumbach K, Judson T, Desai M, et al. Association of race/ ethnicity with likeliness of Covid-19 vaccine uptake among health workers ant the general population in the San Francisco Bay area. JAMA Internal Medicine 2021. https://doi.org/10.1001/jamainternmed.2021.1445

142. Mohamed-Hussein AA, Makhlouf H, Abd El Aal H, et al. A national survey of potential acceptance of Covid-19 vaccines in healthcare workers in Egypt. MedRxiv 2021. https://doi.org/10.1101/2021.01.11.21249324

143. Agyekum MW, Afrifa-Anane GF, Kyei-Arthur F, et al. Acceptability of Covid-19 vaccination among health care workers in Ghana. MedRxiv 2021. https://doi.org/10.1101/2021.03.11.21253374

144. Fonogue JT, Noubom M, Kenfack B, et al. Poor knowledge of Covid-19 and unfavourable perception of the response to the pandemic by healthcare workers at the Bafoussam Regional 
Hospital (West Region-Cameroon). MedRxiv 2020.

https://doi.org/10.1101/2020.08.20.20178970

145. Chawe A, Mfune RL, Syapiila PM, et al. Knowledge, attitude and practices of Covid-19 among medical laboratory professionals in Zambia. African Journal of Laboratory Medicine 2021. https://doi.org/10.1101/2020.09.22.20199240

146. Temsah MH, Barry M, Aljamaah F, et al. Adenovirus and RNA-based Covid-19 vaccines: perceptions and acceptance among healthcare workers. medRxiv 2020.

https://doi.org/10.1101/2020.12.22.20248657

147. Papagiannis D, Malli F, Raptis DG, et al. Assessment of knowledge, attitudes, and practices towards new coronavirus (SARS-CoV-2) of health care professionals in Greece before the outbreak period. International Journal of Environmental Research and Public Health 2020;17:4925-4934. https://doi.org/10.3390/ijerph17144925

148. Rabi R, Moraga B, Nazzal Z, et al. Factors attecting nurses' intention to accept the Covid-19 vaccine: A cross-sectional study. Public Health Nursing 2021.

https://doi.org/10.1111/phn.12907

149. Qattan A, Alshareef N, Alshargi O, et al. Acceptability of a Covid-19 vaccine among healthcare works in the Kingdom of Saudi Arabia. Frontiers in Medicine 2021; 8:83-89.

https://doi.org/10.3389/fmed.2021.644300

150. Askarian M, Fu L, Taghrir MH, et al. Factors affecting Covid-19 vaccination intent among Iranians: Covid-19 vaccination acceptance. SSRN 2020. https://ssrn.com/abstract=3741968.

151. Ruck C, Mataix-Cols D, Malki K, et al. Will the Covid-19 pandemic lead to a tsunami of suicides? A Swedish nationwide analysis of historical and 2020 data. MedRxiv 2020.

https://doi.org/10.1101/2020.12.10.20244699

152. Robichaux C, Sauerland J. The social determinants of health, Covid-19, and Structural competence. The Online Journal of Issues in Nursing 2021.

https://doi.org/10.3912/OJIN.Vol26No02PPT67

153. Daly M, Jones A, Robinson E. Public trust and willingness to vaccinate against Covid-19 in the U.S. from October 14, 2020, to March 29, 2021. JAMA 2021;325:2397-2399.

https://doi.org/10.1001/jama.2021.8246

154. Rosy S, Mandiracioglu A, Sahin S, et al. Vaccine hesitancy of the Covid-19 by health care personnel. International Journal of Clicinal Practice 2021:75: e13917. https://doi.org/10.1111/ijcp.13917

155. Paul E, Steptoe A, Fancourt D. Attitudes towards vaccines and intention to vaccinate against Covid-19: implications for public health communications. The Lancet Regional HealthEurope 2021.

https://doi.org/10.1016/j.lanepe.2020.100012

156. Kursumovic E, Lennane S, Cook TM. Deaths in healthcare workers due to Covid-19: the need for robust data and analysis. Anesthesia 2020. https://doi.org/10.1111/anae.15116

157. Flood CM, Thomas B, Wilson K. Mandatory vaccination for health care workers: an analysis of law and policy. CMAJ 2021;193: e217-e220.

https://doi.org/10.1503/cmaj.202755

\section{COVID-19 VACCINATION ATTITUDES OF HEALTHCARE WORKERS: \\ A SYSTEMATIC REVIEW OF THE LITERATURE AND META-ANALYSIS \\ V. Janušonis}

Keywords: healthcare workers, Covid-19 vaccine, willingness to vaccinate.

Summary

Total, collective immunity is highly dependent on the willingness of healthcare workers to vaccinate Covid-19 vaccine and the degree to which it is realized.

The aim of the study - to review the scope, causes, peculiarities and trends of healthcare workers' willingness to vaccinate with Covid-19 vaccine in different countries.

Material and methods. Analysis, interpretation, grouping and generalization of scientific literature and research, comparative and content analysis.

Results. Healthcare workers in the context of the Covid-19 pandemic are an exceptional part of society. The public monitors and copies their behaviour, including for Covid-19 vaccination.

However healthcare workers are not a homogeneous whole their individual groups have different attitudes to vaccination Covid-19 vaccine. The proportion of healthcare works with willingness to vaccinate Covid-19 vaccine depends on country, religion, ethnicity, gender, education and other components.

Both - vaccination Covid-19 vaccine willingness and reluctance are on under-researched phenomenon and its causes.

In addition, willingness to be vaccinated and vaccination Covid-19 vaccine are not identical and ofen differ significantly. The reasons for all this are a great deal of uncertainty about both - Covid-19 infection and vaccination.

The vaccination Covid-19 vaccine is a major medical, social and political problem.

Conclusions. The willingness of healthcare workers to vaccinate with Covid-19 vaccine is an important factor in managing a pandemic and in encouraging the public to be vaccinated and gaining mass (collective) immunity.

This factor depends on broad context - country, cultural, social and political environment, race, religion, economic development, personal characteristics, etc.

The willingness of healthcare workers as part of society to vaccinate with Covid-19 vaccine are more or less correlated with the vaccination attitude of the population of the country.

Correspondence to: janusonis@kul.lt

Gauta 2021-11-03 